\title{
Determinants of Loyalty Among Customers of Non-Interest Banking Services in Kaduna Metropolis, Nigeria: The Case of Jaiz Bank
}

\author{
Dr. aliyu mamman, \\ Department of Business Management, Faculty of Management Sciences \\ Federal university Dutsinma, Katsina state, Nigeria
}

\begin{abstract}
The study examined the determinants of loyalty among customers of Non-interest Banking services in Kaduna Metropolis with reference to Jaiz Bank. Descriptive and multiple regression statistics were used to analyze the data of the study. The findings of the study indicate that the loyalty of customers of Jaiz Bank is mainly determined by Customer satisfaction involving uniqueness of NIB services offered by the Bank and accessibility of NIB services offered by the Bank; followed by Customer Perception involving positive perception of the Bank due to its compliance to religious belief of prohibition of interest; and finally, Success Philosophy involving long-term consideration of success of the Bank .Based on the findings, the study recommended that the Management of Jaiz bank Plc should maintain or even improve on uniqueness and accessibility of its service. The Bank should also continue to strictly abide by its policy of Non-interest banking so as to maintain the positive perception of customers and their optimism in its success in future.
\end{abstract}

Keywords: Determinants, Non-interest Banking (NIB) Services, Customers and Loyalty

DOI: $10.7176 / \mathrm{JMCR} / 64-04$

Publication date: January $31^{\text {st }} 2020$

\subsection{Introduction}

The introduction of money as a medium of exchange resulted in people acquiring more than they needed to satisfy their immediate needs. The question of where and how to keep the extra arose. Different communities device different means of saving extra funds. In Hausa-Fulani communities the traditional saving system is referred to as "Asusu" and "Adashe" (Ogwezi, 2014). In the "Asusu" system the individual put aside certain amount of money from time to time in a locally made safe called "Gongoni". After a targeted time the "Gongoni" is opened and the money inside is used for a purpose such as marriage ceremony, naming ceremony etc. In the "Adashe" saving system people constitute themselves into groups, contribute money on a periodic basis (daily, weekly, monthly etc) and one of them collect the sum to use it for a purpose.

Though every community has its traditional saving system, saving through the modern commercial banking system takes the lead (Mamman, 2005). The domination of the Western commercial banking system can be attributed to colonialism and imperialism (Khan, 2000). The Western banking system is interest based. Interest is added on deposits and it is charged on loans. In Islam interest is strictly forbidden. In view of this prohibition, Nigeria's $46.7 \%$ population (mostly muslims Hausa-Fulani) is excluded from the formal financial services (Sapovadia, 2015). Alawaiye (2012) also noted that 56 million Nigerians were without bank accounts mainly due to religious belief and ethical consideration.

Globally, financial inclusion has assumed increasing recognition among policy makers. This has resulted in the legalization and practice of Non-interest banking (NIB) in many countries. With the promulgation of Banks and other Financial Institutions Decree (BOFID) 25 of 1991, Nigeria joined the host of other countries in which NIB is legal. Accordingly, an investment holding company known Jaiz International Plc, was granted license to practice NIB. The Bank commenced operations with three branches in Abuja, Kaduna and Kano states in 2012 (Oladimeji and Monisola, 2012).

Establishment of Jaiz Bank has increased the level of competition in the Nigeria's banking industry. The high level competition has made it necessary for banks to embark on relationship marketing activities that will enable them attract new customers, retain existing ones as well as making them loyal. Customer loyalty is fast being recognized as effective competitive strategy and key determinant of long-term profitability in the banking sector (Ukenna, Olise, Chibuike, Anionwu, Igwe and Okoli, 2012). Loyal customers are profitable customers and generate revenue by higher patronage and by recommending new customers.

Despite the importance of customer loyalty in the banking business, past studies appear to have paid less attention to it (Ukenna et al, 2012). The few conducted studies on customer loyalty were in respect of interest based commercial banks, knowledge gap exist on loyalty among customers of NIB services (Badara, Mat, Mujtaba, Al-Refai, Musa and Abubakar, 2013). To contribute in filling this gap, this paper examines the determinants of loyalty among customers of NIB services in Kaduna Metropolis.

Hassan, Bilal, Ahmed, Habib, Riaz, Maqbool and Anwar (2012) used five consructs to measure customers 
loyalty to islamic banks in Pakistan. The consructs are; Customer satisfaction, Switching cost, Trust and commitment, Customer perception and Success philosophy. This study will adopt the five consructs to find out the extent to which each one of them determines loyalty of customers in patronizing the services of Jaiz bank, Kaduna branch. Accordingly, the specific objectives of the study are to determine the impact of (i) Satisfaction on customers loyalty (ii) Switching cost on customers loyalty (iii) Trust and commitment on customers loyalty (iv) Perception on customers loyalty, and (v) Success philosophy on customers loyalty.

\subsection{Literature Review \\ 2.1 Conceptual Framework \\ 2.1.1 Determinants}

Determinant is an element that identifies or determines the nature of something or that fixes or conditions an outcome (www.merriam-webster.com). In the context of this study, determinants are the five elements that determine extent of loyalty of customers patronizing NIB services of Jaiz Bank, Kaduna branch. The elements and their various aspects comprise the following: Customer satisfaction; it is a narketing term that measures how products or services meet or surpass customers' expectations (Beard, 2014). Customers are said to be satisfied if a product or service consumed meet or even supass their expectation and they are dissatisfied if the reverse is the case. Though customers differ in their expectations from products or services they consume, they always care for quality, uniqueness, accessibility, good value, room for expression, promptness, taking of responsibility, empathy, conducive atmosphere and technological advancement (https://www.nbrii.com).

Switching Cost; it is the cost which customers bear to switch from one bank to another (Hassan, et al, 2012). Klemperer(1987) identified three types of switching costs: transaction, learning and contractual. Similarly, Guiltnan (1989) identified four types of switching costs as contractual, set-up, psychological commitment and continuity costs. The author adopted Klemperer's contractual costs while grouping together transaction and learning costs as set-up costs (Caruana, 2003). If customers are satisfied and loyal, switching cost will be high and may prefer to remain with their initial bank. It is important for Non-interest banks to provide better services to their customers so as to make their swithching cost higher. Better services can be inform of improvemment in physical environment and making emphasis on compliance to religious beliefs of customers, which is the unique selling point of the bank.

Trust and Commitment; Trust is the confidence that customers has that NIB banks will not do something harmful or risky with their funds (http://smallbusiness.chron.com). For instance the customers has confidence that their savings are free from interest which is against their belief. NIB customers ought to have confidence that their funds will not be invested in trade activities which are prohibited by Islam such as alcohol, gambling etc. Trust also involves confidence on the honesty and integrity of personnel working in the a bank. Trust usually leads to commitment which involves a long-term desire to maintain a valued relationship with a bank (Morgan and Hunt, 1994). Trust and commitment are positively related with customer loyalty (Hassan et al, 2012)

Customer Perception: it is a process by which a customer selects, organizes, and interprets information/stimuli inputs to create a meaningful picture of a product service (http://www.mbaskool.com). It is a three stage process that involves customers' exposure to information/stimuli, paying attention to it and finally interpret it as positive or negative. Positive perception is positively related with customer loyalty (Hellofs and Jacobson, 1999). NIB banks are expected to provide the kind of information in form of advertisement or words of mouth that will make customers to have positive perception about them. This kind of information may include the unque selling points of NIB such as non-charging of interest, profit and loss sharing, compliance to religiuos beliefs etc

Success Philosophy: NIB banks provide alternatives of interest based banking services. NIB banks in many countries like Pakistan are capturing the market share with a growth rate of $114 \%$ per annum (Hassan et al, 2012). This is a success for NIB banks. Perceived success can also be due to short or long term considerations by customers. For instance large share is a short term criteria for success and sustaining it is a long term one. Perceived success of banks by customers is positively related with customer loyalty (Salegna and Godwin, 2005)

\subsubsection{Customer Loyalty}

Oliver (1999) defines customer loyalty as a deeply held commitment to rebuy or patronize a preferred product or service consistently in the future, despite situational influences and marketing efforts having the potential to cause switching behavior. He maintained that customer loyalty is reached through four sequential stages: Cognitive Loyalty; at this initial stage, loyalty is simply based on customers judgement (arising from the information provided by the banks) of how well the services meet their expectations. The loyalty is superficial in nature as it is not based on real satisfaction; it is simply based on mere information provided by the banks themselves. Affective Loyalty; at this stage customers begin to develop a liking or attitude towards the banks' services based on practical satisfying experiences they had. Though the customer can be emotionally committed to a bank at the affective stage, he can switch to other banks. Conative Loyalty; here the customer develop strong intention of future patronage based on repeated events of postive emotions towards services rendered by a bank. However, this intention may not always lead to actual patronage. Action Loyalty; at this final stage, the 
desire and intention in the conative stage translate into realistic loyalty actions or behaviour. In the context of this study, customer loyalty refers to the final stage of "Action Loyalty".

\subsubsection{NIB Services}

The Central Bank of Nigeria (CBN) defines NIB Services as banking services that are offered in accordance with the principles and rules of Islamic commercial jurisprudence that strictly forbids charging and taking of interest (Sapovadia, 2015). In 2011, the CBN issued a license to Jaiz Bank to operate fully as non-interest bank. The bank commenced operations with three branches in Abuja, Kaduna and Kano states. In 2012 Jaiz Bank opened branches in many other states in Nigeria. The bank, based on its Brochure (2017), offers the following retail, corporate as well as financing products banking services;

- Current Account; it is an account that operates under the principle Qardhasan (Non-interest loan

- Salary Account; it is designed for salary earners to provide easy and convenient to their funds while enjoying host of other professional services from the banks such as Jaiz Kids Account, Jaiz Tier One Account etc

- Jaiz Domiciliary Account; the account is in foreign currencies (Dollar, Pounds and Euro) and is designed to help customers conveniently carry out foreign currency transaction from the comfort of their homes, office or abroad

In the area of financing, Jaiz bank offers the following NIB services;

- Murabaha; it is a financial product mostly used in financing purchase of raw materials, machinery, equipment and customer durables

- $\quad$ Mudaraba; it is a form of partnership in which the bank provides funds and other partner(s) provide labour and profit is shared in a proportion agreed in advance

Musharaka; it is a joint venture between the bank and an individual or business entity to conduct certain business and net profits or losses are shared between the business partners according to the capital invested

- Ijarah; under the scheme, the customer requests the bank (lessor) to purchase capital goods like machinery or equipment and rent it to him or her (lessee)

In the context of this study NIB services refers to the above services being offered by Jaiz Bank, Kaduna branch.

\subsection{Review of Empirical Literature}

A number of studies have been conducted on the determinants of customers loyalty as it relates to the five constructs of the study namely; Customer satisfaction, Switching cost, Trust and commitment, Customer perception and Success philosophy. Odunlami and Matthew (2015) in a study on impact of customer satisfaction on customer loyalty in selected banks in Oyo state, Nigeria discovered that there is a significant relationship between customer satisfaction and customer loyalty. The study indicated that a $1 \%$ shift in customer satisfaction will cause a positive shift of $61.7 \%$ shift in customer loyalty. Shanka (2012) examined the quality of bank's service, satisfaction and loyalty of customers of Ethiopian banking sector. The found that there is positive relationship between customer satisfaction and customer loyalty.

There have not been many studies on the factors that have impact on customers' bank switching behavior (Arshad, Zahra and Draz, 2016). Caruana (2003) in an empirical study on the impact of switching costs on customer loyalty and discovered a positive relationship between switching costs and loyalty. Sarwar, Abbasi and Pervaiz (2012) in their study on the effect of customer trust on customer loyalty and retention in Pakistan, found a positive relationship between trust, Commitment and customer loyalty. Gordon (2003) also observed that the loyalty of committed customers is higher than that uncommitted ones.

Moisescu (2015) studied the impact of customers' perception on customers loyalty in Romania. The study discovered a positive relationship between customers' positive perception of service quality and loyalty. Siddiqi (2011) conducted a study on the relationship between customers perception of service quality and customer loyalty. The study which involved 100 retail banking customers in Bangladesh discovered that customers' positive perception of quality service quality is positively related to customer loyalty. Salami and Olanye (2013) examined the relationship between customers' perception about service quality and loyalty in selected banks in Asaba, Nigeria. The population of the study comprised 300 customers randomly selected from the five selected banks located in Asaba metropolis. The study also found a positive relationship between customers' positive perception of service quality and loyalty.

As for "Success Philosophy" determinant, the 2014 report of the World Bank Global Islamic Finance Development Centre, indicated NIB services have expanded rapidly over the past decade, growing at 10-12\% annually. Sapovadia (2015) discovered that NIB or Sharia compliant assets are estimated at roughly US\$2 trillion, covering bank and non-bank financial institutions, capital markets, money markets and insurance. Khaf (2011) noted other success criteria in the NIB industry to include high return on investment, minimum idle assets and economies of scale. Hassan et al (2012) maintained that NIB banks are gaining customers' loyalty in many 
countries, including Nigeria, due to the success they are gaining in the global banking arena.

Apart from the studies conducted on the specific determinants of customers' loyalty, studies were also conducted on the collective impact of the determinants. Ukenna et al (2012) conducted a study on drivers of bank loyalty among students in Nigeria. The study found that customer satisfaction is the highest driver of loyalty among students from 4 tertiary institutions in the South-eastern Nigeria. This finding was supported by the study of Hassan et al (2012) in Pakistan. Hashim (2014) examined determinants of customer loyalty among subscribers of global system for mobile (GSM) communication in North-western Nigeria. The study discovered that customer perception of service quality is the highest determinant of loyalty among subscribers or customers of GSM services in the North-western Nigeria.

\subsection{Methodology}

This study adopts the cross-sectional survey research design. The design is considered appropriate due to the fact that the data for the study was collected at the same time. The population of the study comprises all customers of Jaiz Bank residing in Kaduna metropolis. According to the statistics obtained from the Bank, there are total of 26,252 customers. Based on the formula for determining sample size given by Yamane as cited in Israel (2013), a sample size of 394 was determined as follows:

$$
\begin{gathered}
1+26,252 \times(0.05)^{2} \\
\quad=394
\end{gathered}
$$

Data was collected from primary source by means of a structured questionnaire administered on the sampled customers of the bank. The items on the questionnaire were based on the five point Likert scale ranging from 5 (Strongly Agree) to 1 (Strongly Disagree). Area random sampling technique was used in the selection of sample subjects across the metropolis. Descriptive and inferential statistics are used in analyzing the data collected. Descriptive statistics in the form of frequency and percentage are used to analyze the demographic data about the respondents. Inferential statistics in the form of multiple regressions are used to determine the effect of Customer satisfaction, Switching cost, Trust and commitment, Customer perception and Success philosophy on loyalty of customers to Jaiz Bank.

The data gathered from completed copies of the research instrument were analysed using inferential statistics (logistic regression model). The inferential statistics were performed using Statistical Package for Social Scientists (SPSS) computer software (version 16).

A logistic regression predicts the probability that an observation falls into one of two categories of a dichotomous dependent variable based on one or more independent variables that can be either continuous or categorical. Generally, logistic regression is well suited for describing and testing hypotheses about relationships between a categorical outcome variable and one or more categorical or continuous predictor variables. Logistic regression solves problems by applying the logit transformation to the dependent variable. In essence, the logistic model predicts the logit of $Y$ from $X$. The logit is the natural logarithm $(\operatorname{Ln})$ of odds of $Y$, and odds are ratios of probabilities $\left(\mathrm{P}_{\mathrm{i}}\right)$ of $Y$ happening to probabilities $\left(1-\mathrm{P}_{\mathrm{i}}\right)$ of $Y$ not happening (Peng, Lee, and Ingersoll, 2002).

The simple logistic model has the form:

$\operatorname{logit}(Y)=$ natural $\log ($ odds $)=\mathrm{L}_{\mathrm{i}}=\left(\mathrm{P}_{\mathrm{i}} \div 1-\mathrm{P}_{\mathrm{i}}\right)=\alpha+\beta X$

..................................................................

Taking the antilog of equation 1 on both sides, one derives an equation to predict the probability of the occurrence of the outcome of interest as follows:

$\mathrm{P}_{\mathrm{i}}=$ Probability $(Y=$ outcome of interest $\mid X=x$, a specific value of $X)=\mathrm{L}_{\mathrm{i}}=\mathrm{P}_{\mathrm{i}} \div\left(1-\mathrm{P}_{\mathrm{i}}\right)=1+\mathrm{e}_{\mathrm{i}} \div 1-(1+$ $\left.\mathrm{e}^{\mathrm{z}} \mathrm{i}\right) \ldots \ldots \ldots \ldots . . .2$

Where:

$\mathrm{P}_{\mathrm{i}}=$ is the probability of the outcome of interest or "event,"

$\alpha=$ the $Y$ intercept,

$\beta=$ the regression coefficient, and

$\mathrm{e}=2.71828$ is the base of the system of natural logarithms

Source: Peng, Lee, and Ingersoll (2002).

$X$ can be categorical or continuous, but $Y$ is always categorical. According to equation 1, the relationship between logit $(Y)$ and $X$ is linear. Yet, according to equation 2, the relationship between the probability of $Y$ and $X$ is nonlinear. The value of the coefficient $\beta$ determines the direction of the relationship between $X$ and the logit of $Y$. When $\beta$ is greater than zero, larger (or smaller) $X$ values are associated with larger (or smaller) logits of $Y$. Conversely, if $\beta$ is less than zero, larger (or smaller) $X$ values are associated with smaller (or larger) logits of $Y$. Within the framework of inferential statistics, the null hypothesis states that $\beta$ equals zero, or there is no linear relationship in the population under study. Rejecting such a null hypothesis implies that a linear relationship exists between $X$ and the logit of $Y$ (Peng, Lee, and Ingersoll, 2002).

Extending the logic of the simple logistic regression to multiple predictors (say $X_{1}=$ My expectations are met on quality in NIB services offered by Jaiz Bank, $X_{2}=$ My expectations are met on uniqueness of NIB 
services offered by Jaiz Bank, $X_{3}=$ My expectations are met on accessibility of NIB services offered by Jaiz Bank, $X_{4}=$ My expectations are met on good value of NIB services offered by Jaiz Bank, $X_{5}=$ NIB services offered by Jaiz Bank met my expectation of self expression, $X_{6}=$ My expectations are met on room for self expression in respect of NIB services offered by Jaiz Bank, $X_{7}=$ My expectations are met on promptness with regards to NIB services offered by Jaiz Bank, $X_{8}=$ My expectations are met on empathy with regards to NIB services offered by Jaiz Bank, $X_{9}=$ My expectations are met on conducive atmosphere with regards to NIB services offered by Jaiz Bank, $X_{10}=$ My expectations are met on technological advancement with respect to NIB services offered by Jaiz Bank, $X_{11}=$ I may not switch to other banks due to Non-availability of NIB services, $X_{12}$ $=\mathrm{I}$ may not switch to other banks due to lovely environment of Jaiz Bank, $X_{13}=\mathrm{I}$ may not switch to interestbased banks due to my religious belief of prohibition of interest-based transactions, $X_{14}=\mathrm{I}$ have confidence that my savings are free from interest which is against my religious belief, $X_{15}=\mathrm{I}$ have confidence in the honesty of staff of Jaiz Bank, $X_{16}=$ I have confidence in the integrity of staff of Jaiz Bank, $X_{17}=$ My positive perception of Jaiz is Bank is mainly due to non-adding and charging of interest on savings and loans respectively, $X_{18}=\mathrm{My}$ positive perception of Jaiz Bank is mainly due to its compliance to my religious belief of prohibition of interest, $X_{19}=$ My positive perception of Jaiz Bank is mainly due to its profit and loss sharing arrangement, $X_{20}=$ My patronage of Jaiz Bank is due to its large customership, $X_{21}=$ My patronage of Jaiz Bank is due to its easy access, $X_{22}=$ My patronage of Jaiz Bank is due to its long-term consideration of success), one can construct a complex logistic regression for $Y$ (customer loyalty) as follows:

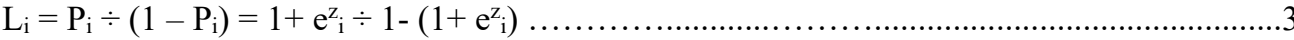

So that:

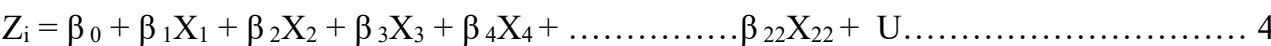

$\beta_{1}, \beta_{2}, \beta_{3} \beta_{4} \ldots \ldots \ldots \ldots . . . \beta_{22} X_{22}$ are the co-efficient of $X s$

$\beta_{0}=$ intercept

$\mathrm{U}=$ disturbance term

Empirically:

$\mathrm{L}_{\mathrm{i}}=\mathrm{e}^{\mathrm{z}}{ }_{\mathrm{i}}$ .5

Where; $Z_{i}=\beta_{0}+\beta_{1} X_{1}+\beta_{2} X_{2}+\beta_{3} X_{3}+\beta_{4} X_{4}+\beta_{5} X_{5}+\beta_{6} X_{6}+\beta_{7} X_{7}+\beta_{8} X_{8}+\beta_{9} X_{9}+\beta_{10} X_{10}+\beta_{11} X_{11}+\beta_{12} X_{12}+$ $\beta_{13} X_{13}+\beta_{14} X_{14}+\beta_{15} X_{15}+\beta_{16} X_{16}+\beta_{17} X_{17}+\beta_{18} X_{18}+\beta_{19} X_{19}+\beta_{20} X_{20}+\beta_{21} X_{21}+\beta_{22} X_{22}+$

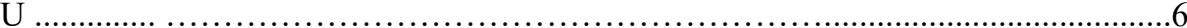

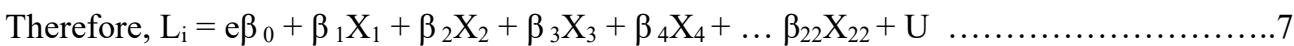

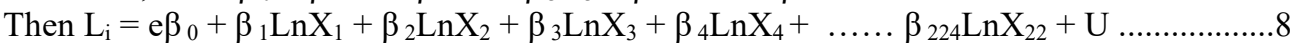

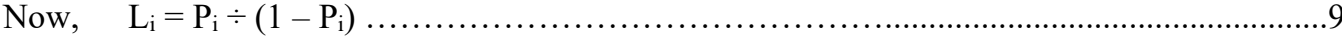

Where:

$\mathrm{L}_{\mathrm{i}}=$ logit model (customer loyalty)

$\mathrm{e}=$ exponential

$\mathrm{Z}_{\mathrm{i}}=$ estimates

$\beta_{0}=$ intercept

$\beta_{1}=$ slope of My expectations are met on quality in NIB services offered by Jaiz Bank

$\beta_{2}=$ slope of My expectations are met on uniqueness of NIB services offered by Jaiz Bank

$\beta_{3}=$ slope of My expectations are met on accessibility of NIB services offered by Jaiz Bank

$\beta_{4}=$ slope of My expectations are met on good value of NIB services offered by Jaiz Bank

$\beta_{5}=$ slope of NIB services offered by Jaiz Bank met my expectation of self expression

$\beta_{6}=$ slope of My expectations are met on room for self expression in respect of NIB services offered by Jaiz Bank

$\beta_{7}=$ slope of My expectations are met on promptness with regards to NIB services offered by Jaiz Bank

$\beta_{8}=$ slope of My expectations are met on empathy with regards to NIB services offered by Jaiz Bank

$\beta_{9}=$ slope of My expectations are met on conducive atmosphere with regards to NIB services offered by Jaiz Bank

$\beta_{10}=$ slope of My expectations are met on technological advancement with respect to NIB services offered by Jaiz Bank

$\beta_{11}=$ slope of I may not switch to other banks due to Non-availability of NIB services

$\beta_{12}=$ slope of I may not switch to other banks due to lovely environment of Jaiz Bank

$\beta_{13}=$ slope of I may not switch to interest-based banks due to my religious belief of prohibition of interest-based transactions

$\beta_{14}=$ slope of I have confidence that my savings are free from interest which is against my religious belief

$\beta_{15}=$ slope of I have confidence in the honesty of staff of Jaiz Bank

$\beta_{16}=$ slope of I have confidence in the integrity of staff of Jaiz Bank

$\beta_{17}=$ slope of My positive perception of Jaiz is Bank is mainly due to non-adding and charging of interest on savings and loans respectively

$\beta_{18}=$ slope of My positive perception of Jaiz Bank is mainly due to its compliance to my religious belief of 
prohibition of interest

$\beta_{19}=$ slope of My positive perception of Jaiz Bank is mainly due to its profit and loss sharing arrangement

$\beta_{20}=$ slope of My patronage of Jaiz Bank is due to its large customership

$\beta_{21}=$ slope of My patronage of Jaiz Bank is due to its easy access

$\beta_{22}=$ slope of My patronage of Jaiz Bank is due to its long-term consideration of success

$\mathrm{U}=$ error term

The null hypothesis underlying the overall model states that all $\beta$ s equal zero. A rejection of this null hypothesis implies that at least one $\beta$ does not equal zero in the population, which means that the logistic regression equation predicts the probability of the outcome better than the mean of the dependent variable $Y$. On a-priori, $P i$ is $<1$ and the expected pattern of the structural behaviours of the independent variables on the dependent variable is greater than zero.

\subsection{Results and Discussion}

Table 1: Omnibus Test of Model Coefficients

\begin{tabular}{|c|l|l|l|}
\hline & Chi-square & Df & Sig. \\
\hline Step 1 Step & 163.778 & 22 & .000 \\
Block & 163.778 & 22 & .000 \\
Model & 163.778 & 22 & .000 \\
\hline
\end{tabular}

Source: SPSS output from field survey data

Table 2: Hosmer and Lemeshow Test

\begin{tabular}{|l|l|l|l|}
\hline Step & Chi-square & Df & Sig. \\
\hline 1 & 8.538 & 8 & .383 \\
\hline
\end{tabular}

Source: SPSS output from field survey data

Table 3: Model Summary

\begin{tabular}{|l|l|l|l|}
\hline Step & -2 Log likelihood & Cox \& Snell R Square & Nagelkerke R Square \\
\hline 1 & $85.927^{\mathbf{a}}$ & .519 & .772 \\
\hline
\end{tabular}

Source: SPSS output from field survey data

Table 1 above depicts the Omnibus Test of Model Coefficients, which give the overall indication of how well the model performs ('goodness of fit' test). For this set of results, the requirement is a highly significant value (the Sig. value should be less than 0.05) (Pallant, 2007). In this study, the Sig. value is 0.000 (which really means $\mathrm{p}<0.005)$. Therefore, the set of variables in the analysis fits the model. Similarly, the chi-square value is 163.778 with 8 degrees of freedom. In addition, Table 2 shows Hosmer and Lemeshow Test. The results in Table 2 support the model of this study as being worthwhile. For the Hosmer-Lemeshow Goodness of Fit Test, poor fit is indicated by a significance value less than 0.05 , so to show support for a model a value greater than 0.05 is required (Pallant, 2007). For this study the chi-square value is 8.538 with a significance level of 0.383 . This value is larger than 0.05 , therefore indicating a support for the model of this study.

Table 3 is the Model Summary and it contains the Cox and Snell R Square, and the Nagelkerke R Square values, which indicate the amount of variation in the dependent variable explained by the model (from a minimum value of 0 to a maximum value of approximately 1). These are described as pseudo $\mathrm{R}$ square statistics rather than true R square (Pallant, 2007). Therefore, the explained variation in the dependent variable based on the model of this study ranges from $51.9 \%$ to $77.2 \%$, suggesting that between $51.9 \%$ and $77.2 \%$ of the variability in Jaiz Bank NIB customers' loyalty in Kaduna Metropolis was explained by the set variables (My expectations are met on quality in NIB services offered by Jaiz Bank, My expectations are met on uniqueness of NIB services offered by Jaiz Bank, My expectations are met on accessibility of NIB services offered by Jaiz Bank, My expectations are met on good value of NIB services offered by Jaiz Bank, NIB services offered by Jaiz Bank met my expectations of self expression, My expectations are met on room for self expression in respect of NIB services offered by Jaiz Bank, My expectations are met on promptness with regards to NIB services offered by Jaiz Bank, My expectations are met on empathy with regards to NIB services offered by Jaiz Bank, My expectations are met on conducive atmosphere with regards to NIB services offered by Jaiz Bank, My expectations are met on technological advancement with respect to NIB services offered by Jaiz Bank, I may not switch to other banks due to Non-availability of NIB services, I may not switch to other banks due to lovely environment of Jaiz Bank, I may not switch to interest-based banks due to my religious belief of prohibition of interest-based transactions, I have confidence that my savings are free from interest which is against my religious belief, I have confidence in the honesty of staff of Jaiz Bank, I have confidence in the integrity of staff of Jaiz Bank, My positive perception of Jaiz is Bank is mainly due to non-adding and charging of interest on savings and loans respectively, My positive perception of Jaiz Bank is mainly due to its compliance to my religious belief of prohibition of interest, My positive perception of Jaiz Bank is mainly due to its profit and loss sharing 
arrangement, My patronage of Jaiz Bank is due to its large customership, My patronage of Jaiz Bank is due to its easy access, My patronage of Jaiz Bank is due to its long-term consideration of success).

Furthermore, table 4 on appendix I presents the Variables in the equation, which gives information about the contribution or importance of each of the predictor variables. The test that is used here is the Wald test, and the values in the Sig. column are used to indicate the significant contribution of each predictor variable in the model. The Sig. values of less than 0.05 are the variables that significantly contribute to the predictive ability of the model (Pallant, 2007). In the model of this study, the significant variables comprise (my expectations are met on uniqueness of NIB services offered by Jaiz Bank, Sig. $=0.038$; my expectations are met on accessibility of NIB services offered by Jaiz Bank, Sig. $=0.004$; my positive perception of Jaiz Bank is mainly due to its compliance to my religious belief of prohibition of interest, Sig. $=0.043$, my patronage of Jaiz Bank is due to its easy access, Sig. $=0.004$; and my patronage of Jaiz Bank is due to its long-term consideration of success, Sig. = 0.000), that is to say the major factors influencing whether a Jaiz Bank customer will reports loyalty to NIB services are: Customer satisfaction involving uniqueness of NIB services offered by Jaiz Bank and accessibility of NIB services offered by Jaiz Bank which is in line with the findings of Olunlami and Mathew (2015) and Shanka (2012); Customer Perception involving positive perception of Jaiz Bank due to its compliance to religious belief of prohibition of interest which agrees with the findings of Siddiqi (2012) and Salami andOlanye (2013); and finally, Success Philosophy involving long-term consideration of success of Jaiz Bank, which also agrees with the findings of Sapovadia (2015) and Hassan et al (2012).

\subsection{Conclusions}

From the results presented above, this study concludes that between $51.9 \%$ and $77.2 \%$ of the variability in Jaiz Bank NIB customers' loyalty in Kaduna Metropolis was explained by the set variables (customer satisfaction, switching costs, trust and commitment, perception, and success philosophy). Another important conclusion that can be drawn from the results of this study is that there is a significant relationship between customer satisfaction, customer perception, and success philosophy and customer loyalty in Jaiz Bank. The relationship between trust and commitment and switching costs and customer loyalty is not a significant one in Jaiz Bank.

Similarly, based on the results above it can also be concluded that the major specific factors determining loyalty of customers to Jaiz Bank are; meeting expectations on uniqueness of NIB services offered by the Bank, meeting expectations on accessibility of NIB services offered by the Bank, positive perception of the Bank mainly due to its compliance to religious belief of prohibition of interest, and long-term consideration of the Bank’s success.

\subsection{Recommendations}

From the conclusions above, this study recommends the followings;

a. Jaiz Bank should continue to maintain the tempo in the delivery of quality and efficient NIB services to its customers;

b. Jaiz Bank should continue to maintain loyalty of their customers by offering NIB services that satisfy them in terms of uniqueness and difference from services offered by other banks

c. Jaiz Bank should continue to offer NIB services that meet the expectation of its customers in terms of accessibility and long-term consideration of success;

d. Jaiz Bank should continue to create confidence in the minds of its customers by offering unique NIB services that complied with the religious belief of the majority of the customers; and

e. Jaiz Bank should deploy advanced technology in the delivery of NIB services offered to its customers.

\section{References}

Alawaiye, A. (2012, November 30). 56 Million Adults Have no Account. The Punch .

Arshad, T., Zahra, R., \& Draz, U. (2016). Impact of Customer Satisfaction on Image, Trust, Loyalty and the Customer Switching Behavior in Conventional and Islamic Banking: Evidence from Pakistan. American Journal of Business and Society, Vol.1 No 3 , 154-165.

Badar, S., Mat, N. K., Mujtaba, A. M., Al-Refai, A. N., Musa, A. B., \& Abubakar, F. M. (2013). Direct Effect of Service Quality Dimensions on Customer Satisfaction and Customer Loyalty in Nigerian Islamic Bank. Management 3 (1) , 6-11.

Beard, R. (2014, January 20). Why Customer Satisfaction is Important. Retrieved Otober 15, 2017, from http://blog.clientheartbeat.com.

Caruana, A. (2003). The Impact of Switching Costs on Customer Loyalty: A Study among Corporate Customers of Mobile Telephony. Journal of Targeting, Measurement and Analysis for Marketing, Vol. 12, 3, 256-268.

Gordon, F. (2003). When Does Commitment Lead to Loyalty? Journal of Service Research, Vol.5 No. 4 , 333 344.

Guiltnan, J. (1989). A Classification of Switching Costs with Implicationss for Relationship Marketing. Winter 
Educators' Conference (pp. 216-220). Chicago: American Marketing Association.

Hashim, A. (2014). Determinants of Customer Loyalty among Subscribers of Global System for Mobile (GSM) Communication in North-western Nigeria. The 2014 WEI Internatinal Academic Conference Proceedings (pp. 119-129). New Orleans, USA: The West East Institute.

Hassan, T., Bilal, A., Ahmed, S., Habib, U., Riaz, S., Maqbool, N., et al. (2012). Measuring Customers Loyalty of Islamic Banking in Bahawalpur Region. International Journal of Learning and Development, Vol. 2 No. $2,101-111$.

Hellofs, L., \& Jacobson, R. (1999). Market Share and Customers' Perceptions of Quality: When can Firms Grow their Way to Higher versus Lower Quality? Journal of Marketing 63 (1) , 16-27.

Israel, L. (2013, January 15). Determining Sample Size. Retrieved July 15, 2017, from http://edis.ifas.ufl.edu/pd006.

Khan, A. (2000). Islamic Banking and its Operations. London: Institute of Islamic Banking and Insurance.

Klemperer, P. (1987). Markets with Switching Costs. The Quarterly Journal of Economics, Vol. 102, 375-394.

Mamman, A. (2005). Marketability of Non-interest Banking Services in the Urban Areas of North-Western Nigeria. Usmanu Danfodio University Sokoto: (Unpublisshed Ph.D Thesis).

Moisescu, O. I. (2015). The Impact of Customers' Perception of CSR on Corporate Brand Loyalty: The Case of the Romanian Mobile Teleom Industry . Central Euaropean Business Review, 21-30.

Morgan, R., \& Hunt, S. (1994). The Commitment Trust Theory of Relationship Marketing. Journal of Marketing, Vol.58, 20-38.

Odunlami, B., \& Matthew, A. O. (2015). Impact of Customer Satisfaction on Customer Loyalty: A Case Study of a Reputable Bank in Oyo, Oyo State, Nigeria. International Journal of Management Studies and Research, 59-69.

Ogwezi, O. (2014). Women in Traditional Banking in Africa: The Nigerian Experience. Journal of Social and Management Sciences, Vol.1 No.1 , 118-123.

Oladimeji, D. A., \& Monisola, E. A. (2012). Islamic Banking: The Controversy Over Non-interest Banking System in Nigeria. Arabian Journal of Business and Management Review, Vol.1 No.1 , 65-78.

Oliver, R. (1999). Whence Customers Loyalty? Journal of Marketing, Vol. 63 , 33-44.

Pallant, J. (2007). Survival Manual: A step by step guide to data analysis using SPSS for Windows (3rd ed.). New York: McGraw Hill.

Peng, C.J., Lee, K.L. and Ingersoll, G.M. (2002). An introduction to Logistic regression analysis and reporting. The Journal of Educational Research,96(1): 1-14.

Salami, C., \& Olanye, A. P. (2013). Customer Perception about the Service Quality in Selected Banks in Asaba. Journal of Research in International Business and Management, Vol 3(3), 119-127.

Salegana, G., \& Goodwin, A. S. (2005). Consumer Loyalty to Service Providers: An Integrated Conceptual Model. Journal of Consumer Satisfaction, Dissatisfaction and Complaining Behavior, 18 (1), 51-67.

Sapovadia, V. (2015). Jaiz Bank, Nigeria: A Case Study on Non-interest Bank. Yola: American University of Nigeria.

Sarwar, Z., Abbasi, K. S., \& Saleem, P. (2012). The Effect of Customer Trust on Customer Loyalty and Customer Retention: A Moderating Role of Cause Related Marketing. Global Journal of Management and Business Research, Vol. 2 Issue 6, 26-36.

Shanka, M. (2012). Bank Service Quality, Customer Satisfaction and Loyalty in Ethiopian Banking Sector. Journal of Business Administration and Management Sciences Research, 1 (1) , 1-9.

Siddiqi, O. (2011). Interrelations Between Service Quality Attributes, Customer Satisfaction and Customer Loyalty in the Retail Banking Sector in Bangladesh. International Journal of Business Management, Vol.6 No.3, 12-36.

Ukenna, S., Olise, C. M., Chibuke, V. V., Anionwu, C., Igwe, N. N., \& Okoli, I. E. (2012). Drivers of Bank Loyalty among Students in Nigeria: Positing the 12-Point Student Customer Bank Loyalty Index Model. American Journal of Business and Management, Vol.1 No.3 , 172-176. 
Appendix I

Table 4: Variables in the Equation

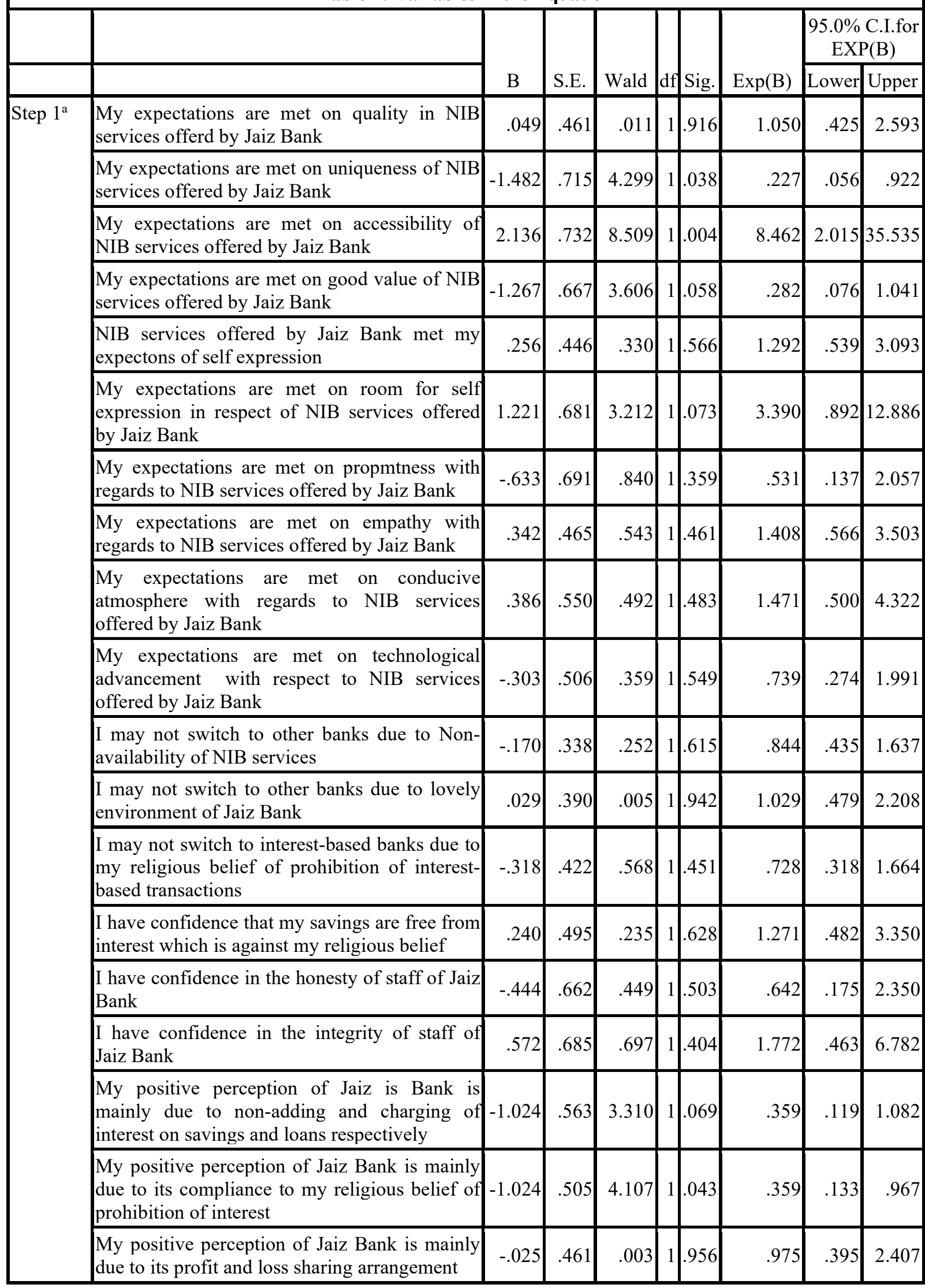




\begin{tabular}{|l|r|r|r|r|r|r|r|r|}
$\begin{array}{l}\text { My patronage of Jaiz Bank is due to its large } \\
\text { customership }\end{array}$ & .202 & .647 & .098 & 1 & .755 & 1.224 & .345 & 4.348 \\
\hline $\begin{array}{l}\text { My patronage of Jaiz Bank is due to its easy } \\
\text { access }\end{array}$ & -1.591 & .558 & 8.144 & 1 & .004 & .204 & .068 & .608 \\
\hline $\begin{array}{l}\text { My patronage of Jaiz Bank is due to its long- } \\
\text { term consideration of success }\end{array}$ & -4.164 & .862 & 23.322 & 1 & .000 & .016 & .003 & .084 \\
\hline Constant & 26.305 & 6.158 & 18.250 & 1 & .000 & $2.656 \mathrm{E} 11$ & & \\
\hline
\end{tabular}

a. Variable(s) entered on step 1: my expectations are met on quality in NIB services offered by Jaiz Bank, my expectations are met on uniqueness of NIB services offered by Jaiz Bank, my expectations are met on accessibility of NIB services offered by Jaiz Bank, my expectations are met on good value of NIB services offered by Jaiz Bank, NIB services offered by Jaiz Bank met my expectations on self expression, NIB services offered by Jaiz Bank met my expectation on taking responsibility, NIB services offered by Jaiz Bank met my expectation on promptness, NIB services offered by Jaiz Bank met my expectation on empathy, NIB services offered by Jaiz Bank met my expectations on conducive atmosphere, NIB services offered by Jaiz Bank met my expectations on technological advancement, I may not switch to other banks due to Non-availability of NIB services, I may not switch to other banks due to lovely environment of JaizBank, I may not switch to interestbased banks due to religious belief, I have confidence that my savings are free from interest in Jaiz Bank, I have confidence in the honesty of staff of JaizBank, I have confidence in the integrity of staff of Jaiz Bank, My positive perception of Jaiz Bank is due NIB services, My positive perception of Jaiz Bank is due to my religious belief, My positive perception of Jaiz Bank is due to its profit and loss sharing, My patronage of Jaiz Bank is due to its large customership, My patronage of Jaiz Bank is due to its easy access, My patronage of Jaiz Bank is due to its long term consideration of success.

Source: SPSS output from field survey data 